DOI: $\underline{\text { https://doi.org/10.24867/15CG03Kulezic }}$

\title{
UPOREDNA ANALIZA ZAŠTITE KOSINE OD NESTABILNOSTI RAZLIČITIM METODAMA
}

\section{COMPARATIVE ANALYSIS OF SLOPE PROTECTION BY DIFFERENT METHODS}

\section{Nikola Kulezić, Fakultet tehničkih nauka, Novi Sad}

\section{Oblast - GRAĐEVINARSTVOi}

Kratak sadržaj - U radu su analizirane metode zaištite kosina od nestabilnosti i optimalna rešenja. Zaštite kosina su analizirane $u$ tri varijante $s$ ciljem da se analizom osnovnih resursa $i$ dinamikom predloži najpovoljnije rešenje.

Ključne reči: stabilnost, kosina, zaštita, potporni zid

Abstract - The paper analizes the methods of protection of slopes from instability and optimal solutions. Slope protection were analyzed in three variants with the aim of proposing the most favorable solutions by analysis of basic resources and dynamics

Keywords: stability, slope, protection, supporting wall

\section{UVOD}

Kada se stvori više nepovoljnih uslova kao što su mogućnost odrona, visok nivo podzemnih voda, tlo manje čvrstoće, blizina susednnih građevina itd., kosina postaje geotehnička građevina za koju je potrebno izraditi projekat, kao i za svaku drugu građevinu. Projekat zaštite kosine je dokument u kojem se definiše geotehnički model s rešenjem za prethodno definisani projektni zadatak.

Postoji dosta metoda za zaštitu kosina od odrona i klizišta. Neke od njih su detaljnije objašnjene u radu.

Te metode su :

- Ugradnja ankera i postavljanje zaštitne mreže

- Mlazno betoniranje (torkret)

- Potporni zidovi

Cilj rada je zaštita i sanacija kosina, kako nakon preduzetih mera ne bi došlo do odrona i klizišta. Analizom nekoliko metoda zaštite, potrebno je doći do optimalnih rešenja.

\section{STABILNOST KOSINA}

Kosina je ravna, zatalasana ili izlomljena ravan na terenu sa različitim nivoima njena dva kraja. Kosine mogu biti prirodne i veštačke (inženjerske). Inženjerske ili veštački stvorene kosine su ili useci ili nasipi. Dva osnovna elementa kosine su njena visina ili rastojanje od podnožja do vrha kosine i kosine koji predstavlja ugao koji zaklapa ravan kosine sa horizontalom.

\section{NAPOMENA:}

Ovaj rad proistekao je iz master rada čiji mentor je bio prof. Igor Peško.

\subsection{Nastanak klizišta}

Iskustvo i opažanja ukazuju da se nestabilnost kosina u većini slučajeva pojavljuje kao klizanje mase tla, kliznog tela, po ravnoj ili zakrivljenoj kliznoj površini (Slika 1). Pri tome se u donjem delu kliznog tela (pri nožici) tlo naguravanjem zbija, dok se u gornjem delu (pri vrhu) ono rastresa. Zbog zatežućih naprezanja u vrhu i zanemarive zatezne čvrstoće tla obično se, posebno u slučaju sitnozrnih tla, otvara zatežuća pukotina koja se, zbog smera pomeranja, može pri površini otkriti kao škarpa. Pojava takve pukotine jasan je znak nestabilnosti kosine već u ranoj fazi njenog nastanka. Pojava zatežuće pukotine upućuje da se ona može pretvoriti u novu kliznu površinu.

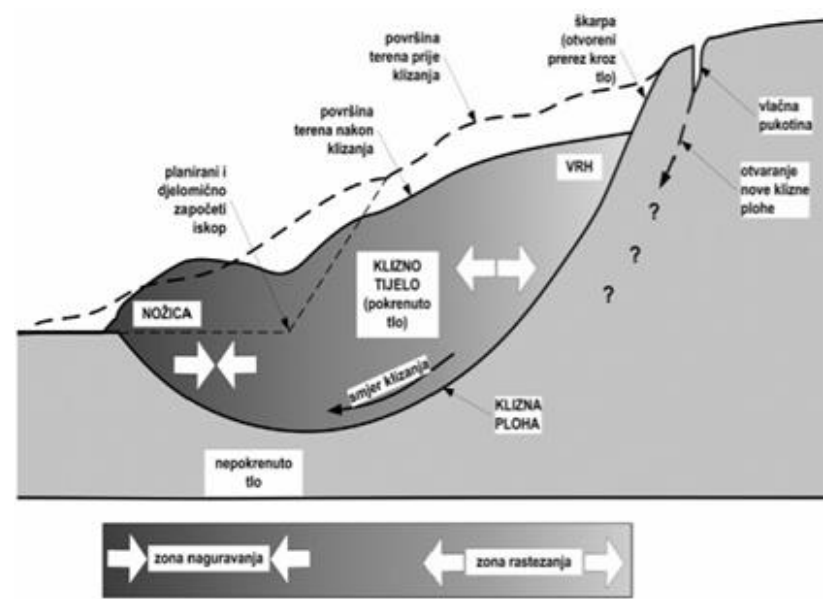

Slika 1. Klizanje mase tla po ravnoj ili zakrivljenoj kliznoj površini

Klizanje kosine se može pojaviti naglo, sa velikim pomeranjima koja se ostvare u kratkom vremenskom intervalu, nakon čega se pokrenuta masa zaustavi u novom ravnotežnom položaju ili klizanje kosina može biti dugotrajan i složen proces.

\section{ZAS̆TITA KOSINE}

Za zaštitu kosine od odrona i klizišta postoji dosta metoda. Na odabir metode utiče mnogo faktora kao što su stepen netabilnosti, sastav tla, geomehaničke karakteristike terena, uslovi izvođenja radova i mnogi drugi.

U ovom radu su detaljnije predstavljene tri metode: zaštita pomoću ankera i mreže, mlaznim betoniranjem i potpornim zidovima. 


\subsection{Zaštita kosine ankerima i mrežom}

Jedna od metoda koja se često koristi za sanaciju kosina je postavljanje zaštitne mreže i bušenje ankera koji mrežu drže za kosinu. Uloga mreže jeste da kosinu štiti od površinske erozije dok sama mreža nema nikakvu statičku ulogu. Statičku ulogu preuzimaju ankeri.

Prilikom sanacije kosine primenjuju se sledeće pozicije radova:

- Pripremni radovi

- Uklanjanje šiblja

- Postavljanje skele

- Čišćenje i kavanje kosine

- Razbijanje i uklanjanje samaca

- Bušenje bušotina

- Ugradnja SN sidara

- Injektiranje ankera zapunjavanjem bušotina

- Postavljane mreže

Faktor sigurnosti kosine se može povećati ugrađivanjem ankera kroz nestabilnu masu tla do odgovarajuće dubine ispod klizne površi. Ankeri doprinose stabilnosti klizne mase tla preko momenta savijanja ankera koji je uklješten u stabilnu masu tla ispod kliznog tela. Potrebno je odrediti najdublju moguću kliznu površ za koju se dobija zadovoljavajući koeficijent sigurnosti

\subsection{Zaštita kosine mlaznim betoniranjem (Torkretiranje)}

Kao i kod prethodne metode prilikom sanacije kosine primenjuju se sledeće pozicije radova:

- Pripremni radovi

- Uklanjanje šiblja

- Postavljanje skele

- Čišćenje i kavanje kosine

- Razbijanje i uklanjanje samaca

- Bušenje bušotina

- Ugradnja SN sidara

- Injektiranje ankera zapunjavanjem bušotina

- Postavljanje armaturne mreže sa fiksiranim ankerima

- Izrada mlaznog betona

\subsection{Zaštita kosine potpornim zidovima}

Kod ove metode prilikom sanacije kosine primenjuju se sledeće pozicije radova:

- Pripremni radovi

- Čišćenje i kavanje kosine

- Zemljani radovi

- Betoniranje podložnog (mršavog) betona

- Armirački radovi

- Tesarski radovi

- Betonski radovi

- Ugradnja drenažnih cevi
Sve radove treba izvesti prema planovima, tehničkom opisu, predmeru i predračunu radova, važećim tehničkim propisima, važećim standardima, kao i uputstvima nadzornog organa.

Sav materijal mora biti kvalitetan, ispitan i po propisima. Svi radovi moraju biti izvedeni savesno i kvalitetno sa stručnom radnom snagom.

\section{UPOREDNA ANALIZA ZAŠTITE KOSINE RAZLIČITIM METODAMA}

Na odabir metode za zaštitu kosine od odrona i klizišta utiče mnogo faktora. Kroz uporednu analizu primenjenih metoda na zaštiti kosina uočavaju se neke ključne stvari, kao što su brzina izvođenja radova, trajanje radova, mehanizacija, ljudski resursi koje dominantno utiču na izbor metode.

\subsection{Potrebna radna snaga za izvrešenje radova}

Tabela 1. I metoda zaštite

\begin{tabular}{|c|c|c|}
\hline Redni broj & Naziv & Broj radnika \\
\hline 1 & Rukovodilac radova & 1 \\
\hline 2 & Bušači & 2 \\
\hline 3 & Pomoćnici bušača & 2 \\
\hline 4 & Injektirci & 1 \\
\hline 5 & Pomoćnici injektiraca & 2 \\
\hline 6 & Bravari & 1 \\
\hline 7 & Električari & 1 \\
\hline 8 & Vozači & 1 \\
\hline 9 & KV radnici & 5 \\
\hline 10 & Pomoćni radnici & 4 \\
\hline
\end{tabular}

Tabela 2. II metoda zaštite

\begin{tabular}{|c|c|c|}
\hline Redni broj & Naziv & Broj radnika \\
\hline 1 & Rukovodilac radova & 2 \\
\hline 2 & Bušači & 2 \\
\hline 3 & Pomoćnici bušača & 1 \\
\hline 4 & Injektirci & 2 \\
\hline 5 & Pomoćnici injektiraca & 1 \\
\hline 6 & Torkretirci & 2 \\
\hline 7 & Pomoćnici torkretiraca & 1 \\
\hline 8 & Bravari & 1 \\
\hline 9 & Električari & 5 \\
\hline 10 & Vozači & 4 \\
\hline 11 & KV radnici & 1 \\
\hline 12 & Pomoćni radnici & 2 \\
\hline
\end{tabular}


Tabela 3. III metoda zaštite

\begin{tabular}{|c|c|c|}
\hline Redni broj & Naziv & Broj radnika \\
\hline 1 & Rukovodilac radova & 1 \\
\hline 2 & Armirači & 5 \\
\hline 3 & Tesari & 5 \\
\hline 4 & Betonirci & 2 \\
\hline 5 & Vozači & 1 \\
\hline 6 & KV radnici & 5 \\
\hline 7 & Pomoćni radnici & 6 \\
\hline
\end{tabular}

Metoda torkretiranja zahteva veću angažovanost visoko kvalifikovane radne snage od metode sanacije kosine upotrebom ankera i mreže, što se ogleda u učešću torkretirca.

Mada metoda izvođenja radova potpornog zida zahteva stručnu radnu snagu tek nekoliko raznih zanimanja, dok su u tom pogledu kod izvođenja radova prve dve metode majstorska zanimanja brojnija, prva metoda je skuplja jer je angažovana radna snaga najobimnija.

\subsection{Analiza vremena}

Za analizu vremena upotrebljeni su podaci iz prethodne tri tabele. Takođe, uzeto je u obzir broj radnika i mehanizacija iz analiza koje su obrađene u radu.

$\mathrm{Na}$ osnovu analiza vremena najkraći vremenski period za završetak radova na sanaciji kosine jeste metodom bušenja ankera i postavljanje mreže. Nešto duži period zahteva metoda zaštite kosine pomoću potpornih zidova, dok metoda mlaznog betoniranja zahteva najviše vremena.

\section{METODE VIŠEKRITERIJUMSKE OPTIMIZACIJE I IZBOR OPTIMALNOG VARIJANTNOG REŠENJA}

Tabela 4.

\begin{tabular}{|c|c|c|c|}
\hline Metoda & M1 & M2 & M3 \\
\hline Mehanizacija & 2 & 3 & 1 \\
\hline
\end{tabular}

Tabela 5.

\begin{tabular}{|c|c|c|c|}
\hline Metoda & M1 & M2 & M3 \\
\hline Mehanizacija & 2 & 3 & 1 \\
\hline
\end{tabular}

Tabela 6.

\begin{tabular}{|c|c|c|c|}
\hline Metoda & M1 & M2 & M3 \\
\hline Troškovi (din) & $\begin{array}{c}3.767 .84 \\
1,70\end{array}$ & $\begin{array}{c}3.951 .921, \\
66\end{array}$ & $\begin{array}{c}5.516 .09 \\
3,25\end{array}$ \\
\hline
\end{tabular}

Tabela 7.

\begin{tabular}{|c|c|c|c|}
\hline Metoda & M1 & M2 & M3 \\
\hline Vreme (dan) & 18 & 31 & 19 \\
\hline
\end{tabular}

Analize rađene metodama kompromisnog programiranja i rangiranja su pokazale da je u svim slučajevima metoda zaštite kosine potpornim zidovima najoptimalnije rešenje.

\section{OSTALE METODE ZAŠTITE KOSINE OD ODRONA I KLIZIŠTA}

Pored pomenutih metoda postoji još dosta načina sanacije kosine. Čest slučaj su kombinacije prethodna tri sistema odbrane.

Te metode su:

- zaštita gredama, stubovima i mrežom

- zaštita gredama, stubovima i mlaznim betoniranjem

- zaštita potpornim zidovima i mlaznim betoniranjem

- zaštita gredama, stubovima, potpornim zidovima i mlaznim betoniranjem

\section{ZAKLJUČAK}

Tokom izrade rada analizirane su metode zaštite kosina od odrona i klizišta. Takođe urađena je uporedna analiza za tri metode sanacije pomoću ankera i mreže, mlaznim betoniranjem i potpornim zidovima. Date su i kombinacije ova tri metode.

Analiziran je tehnološki postupak izvođenja pomenute tri metode, osnovni resursi: materijal, radna snaga, mehanizacija, kao i dinamika izvođenja radova.

Metoda odnosno tehnologija zaštite kosine od odrona zavise od:

- uslova u tlu, vrste tla,

- geomehaničkog sastava u tlu,

- položaja i lokacija kosine,

- izbora i mogućnosti raspoložive tehnologije tj. raspoložive mehanizacije,

- cene sanacije.

Zahtevi koje mora ispuniti zaštita kosina su:

- sigurnost izvođača, njegove opreme i mehanizacije,

- ekonomičnost

- brzo i jednostavno izvođenje.

Da bi to postigli određene rizike pri izvođenju moramo svesti na minimum a to ćemo postići ako:

- za radove koji se ne smeju prekidati osiguramo rezervne mašine i pogone,

- konstantno vršimo kontrolu ugrađenih elemenata i materijala,

- za glavne i specifične radove imamo dobro osposobljen tim radnika

Kada uporedimo sve tri metode dolazimo do sledećih zaključaka.

Činjenica je da metoda izvođenja radova potpornog zida po većini kriterijuma je najskuplja, ali je najpouzdanija tj. najsigurnija za najviše zahteve stabilnosti kosine. Međutim, zbog nepristupačnosti terena, nije svuda moguća primena ove metode pa je u primeni neka druga odgovarajuća. Dakle, izbor metode opredeljuje pre svega mogućnost odabira neke od njih s obzirom na uslove terena, ali koja će obezbediti sigurnost kosine. 


\section{LITERATURA}

[1] Maksimović Milan: „Mehanika tla“, četvrto izdanje, Beograd 2008.

[2] Stojadinović Radoslav: „Mehanika tla, pritisak tla, stabilnost kosina“, Građevinski fakultet u Beogradu, 1980.

[3] Cvetković-Mrkić Sonja: „Geotehničke melioracije“, Rudarsko-geološki fakultet, Beograd 1995.

[4] Roje-Bonacci Tanja: „Mehanika tla“, četvrto izdanje, 2017.

[5] Grubić Nenad: „Stabilnost kosina i sanacija klizišta“, Univerzitet Sarajevo, 2006.

[6] Projekat izrade potpornih zidova, Hotel Surdul, Vranje

\section{Kratka biografija:}

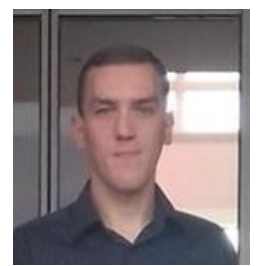

Nikola Kulezić rođen je u Loznici 1988. godine. Master rad na Fakultetu tehničkih nauka iz oblasti Građevinarstva -

Tehnologija i organizacija građenja odbranio je 2021.god 